\title{
Mandarin Chinese Locative Inversion vs. Kinyarwanda Stative Locative Inversion
}

\author{
Jean Paul Ngoboka \\ University of Rwanda \\ College of Education, KG 11 Avenue, Kigali, Rwanda \\ Tel: 250-7-8856-3098Ｅ-mail: jeanngoboka@gmail.com
}

Received: January 16, 2018 Accepted: April 14, 2018 Published: May 1, 2018

doi:10.5296/ijch.v5i1.12490 URL: https://doi.org/10.5296/ijch.v5i1.12490

\begin{abstract}
This study aims to provide a detailed comparison of locative inversion in Mandarin Chinese with -zhe and (stative) locative inversion in Kinyarwanda. After a brief description of these constructions, the study shows that they are similar in many respects and involve similar restrictions despite the fact that the two languages are genetically unrelated: the agent is deleted and disallowed even in a by-agent phrase; the verb belongs to the type of verbs referred to as placement verbs; and it must express a state after the action. These constructions are incompatible with adverbs of manner as well as some placement verbs that do not entail duration after the action, which is typical of stativization. After a detailed comparison of locative inversion in the two languages, it is concluded that despite the fact that the two languages are not related, the locative inversion in Chinese with -zhe has properties similar to those of (stative) locative inversion in Kinyarwanda. It is proposed that although these constructions are referred to as locative inversion, they are primarily stative constructions in which the locative happens to be in a subject position, where it can alternate with the theme.
\end{abstract}

Keywords: Locative inversion, Agent, Stative, Placement verb, Transitive

\section{Introduction}

Kinyarwanda and Mandarin Chinese are two very much genetically unrelated languages. However, there are striking similarities between Mandarin Chinese locative inversion with the imperfective aspect -zhe as described in Pan (1996) and Zhang (2008) and Kinyarwanda stative locative inversion. Consider the Chinese example in (1) and Kinyarwanda example in (2): 
(1) Heibanshang xie -zhe yi ge zi. blackboard-on write ZHE one CL character 'In the blackboard is written a character.'

(2) $\mathrm{Ku}$ kibáahó haanditsehó

ku ki-báahó ha-aandik-ye-hó

(Pan 1996:413)

LOC17 7-blackboard 16.SM-write-ASP $=$ LOC16

inyugúti.

i-nyugúti

'On the blackboard is written a letter.' ${ }^{1}$

AUG-9.letter

Locative inversion is a construction in which a locative expression is in pre-verbal position and the thematic subject post-posed (Bresnan \& Kanerva 1989; Zalzmann, 2011; Marten \& Van der Wal, 2015).

According to Pan (1996), locative inversion is possible with unaccusative verbs, but it is also possible with a transitive verb bearing the imperfective aspect -zhe (as well as -le). However, Pan proposes that the imperfective aspect -zhe, unlike -le, deletes the agent. In other words, when the imperfective aspect morpheme -zhe is used in a locative inversion construction, the agent cannot be expressed in any case as shown by the ungrammaticality of the example in (3):

(3) *Heibanshang John xie-zhe yi ge zi.

blackboard-on John write ZHE one CL character

(On the blackboard, John wrote a character.) (Pan, 1996:414)

Pan states that constructions such as (1) are possible with a specific type of transitive verbs, those verbs that he refers to as placement verbs (e.g. 'write', 'print'). Moreover such verbs must be temporary stative and durative predicates, i.e. those that express the state after the finishing point of an action, which holds for a period of time. This type of locative inversion is not possible with other transitive verbs such as 'beat', which are resultative verbs that focus on the completion of an action. This explains the ungrammaticality of (4b) below:

$\begin{array}{lllll}\text { (4) a. John zai jiali da Bill. } \\ \text { John } & \text { at home-inside beat } & \text { Bill }\end{array}$

John is beating Bill at home.

b. *Jiali da -ZHE Bill.

home-inside beat ZHE Bill

(Lit.: Someone is beating Bill at home.) (Pan, 1996: 425)

What is stated above about Mandarin Chinese is also true for Kinyarwanda. Besides allowing locative inversion with transitive verbs, Kinyarwanda has a form of locative inversion, which I refer to as stative locative inversion, in which the agent must be deleted as is illustrated by (5).

\footnotetext{
${ }^{1}$ Kinyarwanda examples are presented in four lines. Line 1 represents vowel lengthening, surface tone, and phonologically conditioned sound changes. Line 2 presents the underlying morphemes and lexical tone while lines 3 and 4 represent the interlinear glosses and a translation respectively. Glosses are marked as follows: 1,2 $\mathrm{S} / \mathrm{P}=$ first, second person singular/plural; $\mathrm{APPL}=$ applicative; $\mathrm{ASP}=\mathrm{aspect} ; \mathrm{AUG}=$ augment; $\mathrm{DJ}=$ disjoint verb form; $\mathrm{FUT}=$ future tense; $\mathrm{LOC}=$ locative; $\mathrm{RECP}=$ recent past tense; $\mathrm{REMP}=$ remote past tense $\mathrm{SM}=$ subject marker
} 
(5) Ku kibáahó haanditsehó 2018, Vol. 5, No. 1

$\begin{array}{lllcl}\mathrm{ku} & \text { ki-báahó } & \text { ha-aandik-ye-hó } & \text { i-nyugúti } & \text { Yohaáni } \\ \text { LOC18 } & \text { 7-blackboard } & \text { 16.SM-write-ASP=LOC16 } & \text { AUG-9.letter } & \text { John }\end{array}$

'On the blackboard is written a letter (by John).'

I call this type of locative inversion 'stative' locative inversion because the verb is stativized (see details in section 3.2 below).

Also, like in Mandarin Chinese, stative locative inversion in Kinyarwanda is possible only with those verbs which Pan refers to as placement verbs such as 'write' and 'draw'. The Kinyarwanda example in (6b) below, which is analogous to the ungrammatical example in Mandarin Chinese in (4), is also ungrammatical because, unlike in (2), the verb is not a placement verb.

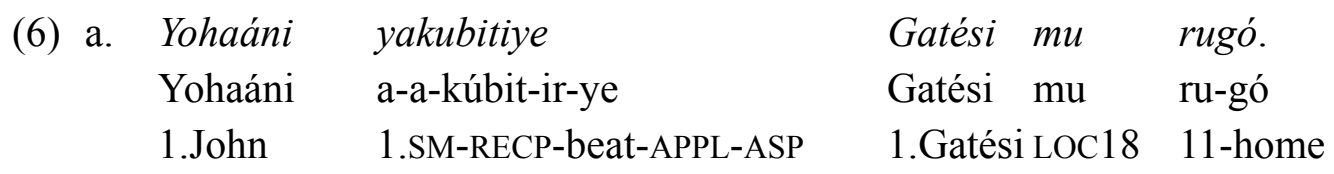

'John beat Gatesi at home.'

$\begin{array}{llll}\text { b. }{ }^{*} M u & \text { rugó } & \text { haakubitiye(yó) } & \text { Gatési. } \\ \text { mu } & \text { ru-gó } & \text { ha-a-kúbit-ir-ye(yó) } & \text { Gatési } \\ \text { LOC18 } & \text { 11-home } & \text { 16.SM-beat-APPL-ASP(=LOC19) } & \text { Gatési }\end{array}$

'At home was Gatesi beaten.'

This paper aims to establish parallels between Chinese locative inversion (Pan, 1996) and Kinyarwanda stative locative inversion. It will be shown that the two constructions exhibit very similar syntactic properties and same restrictions. After providing the contexts in which the two constructions are possible, I proceed with a detailed comparison, showing that they share the property of being stative.

In section 2, I provide an overview of locative inversion in Chinese, with examples taken from Pan (1996) and Zhang (2008). Section 3 provides a background of locative inversion in Kinyarwanda referred to as stative locative inversion, which corresponds to Mandarin Chinese locative inversion with the suffix -zhe. In section 4, I draw parallels between Chinese locative inversion and Kinyarwanda stative locative inversion. In section 5, it is shown that what is referred to as Chinese locative inversion with -zhe and Kinyarwanda stative locative inversion should first and foremost be analyzed as stative constructions before being called locative inversion. Section 6 is a brief summary.

\section{Mandarin Chinese Locative Inversion}

Pan (1996) notes that Mandarin Chinese Locative inversion is possible with unaccusative verbs and passivized verbs as predicted by Bresnan and Kanerva (1989).

Pan shows that despite the unaccusativity nature of locative inversion, transitive verbs in Mandarin Chinese can also appear in locative inversion in a non-passivized form ${ }^{2}$, which is also possible with two aspectual morphemes -le and -zhe.

\footnotetext{
${ }^{2}$ It should be noted here that locative inversion with transitive verbs has been reported to be possible in other languages (Khumalo, 2010; Marten, 2006; Marten, Kula, \& Thwala, 2007; Marten \& van der Wal, 2015; Ngoboka, 2016; Zalzmann, 2011).
} 
(7) Mingpianshang yin -zhe san ge dianhuahaoma. name-card-on print ZHE three CL phone-number

'On the name card is printed three phone numbers.'

(Pan, 1996:413)

(8) Mingpianshang yin -le san ge dianhuahaoma. name-card-on print PERF three CL phone-number

'On the name card is printed three phone numbers.'

The difference between the two constructions is as follows: in locative inversion with non-passivized transitive verbs, -le can co-occur with the agent but -zhe never co-occurs with the agent. Witness the ungrammaticality of (9a) and the grammaticality of (9b).

(9) a. *Zhuozishang John fang-zhe yi ben shu.

table-top John put ZHE one CL book

'John is putting a book on the table.'

b. Zhuozishang John fang-le yi ben shu. table-top John put PERF one CL book

'John put a book on the table.'

(Pan, 1996:410)

Because of the contrast between (9a) and (9b), Pan proposes that -zhe deletes the agent role in a locative inversion, which he analyses as a "morphological operation".

As this paper is concerned with parallels between locative inversion with the morpheme -zhe in Mandarin Chinese and the stative locative inversion in Kinyarwanda (with -ye), below I discuss facts about locative inversion with $-z$ he in Mandarin Chinese as presented by Pan. My discussion of the similarities between the two languages will be based on the following facts:

(i) Locative inversion with -zhe is not possible with all transitive verbs: it is possible with the following transitive verbs, which are referred to as placement verbs: write, curve, paint, hang, stick (see the examples in (1) and (7) above).

(ii) In Mandarin Chinese locative inversion with $-z h e$, the agent must be deleted. If it is expressed, the sentence becomes ungrammatical (see the example in (3) above).

(iii) Impossibility of omitting the postverbal theme NP: while comparing locative inversion constructions with -zhe and -le, Zhang (2008) points out that it is not possible to omit the postverbal NP with -zhe but its omission is possible with -le.
a. zhe zhang zhi
shang (yijing) xie le (zi),
ni xie na zhang ba.
this CLS paper on already write LE character, you write that CLS particle
"This piece of paper is already written on. You write on the other one.'
b. zhe zhang zhi shang xie zhe *(zi), ni xie na zhang ba.

[Zhang 2008:897]

(iv) Besides locative inversion, there is a construction in which the theme is mapped to the subject function, leaving the locative expression behind, as is shown in (11).

$\begin{array}{lll}\text { Nage zi zai heibanshang xie -zhe. } & \\ \text { that character at blackboard-on write ZHE }\end{array}$

'That character is written on the blackboard.'

(Pan 1996:413)

(v) Impossibility of locative inversion with -zhe with some placement verbs: some placement verbs, specifically resultative verb compounds, do not appear in Mandarin Chinese locative inversion. This is illustrated by the verb fang 'put'; although it is a placement verb of the structure agent-theme-location, it is prohibited in Mandarin Chinese locative inversion with 
$-z h e$.

$\begin{array}{llll}\text { *Zhuozishang fang man } & \text {-zhe } & \text { shu. } \\ \text { table-top } & \text { put full } & \text { ZHE } & \text { book } \\ \text { 'Books are put all over the table.' } & \text { (Pan, 1996: 428) }\end{array}$

As Pan suggests, the ungrammaticality of (12) is due to the fact that fang 'put' is a resultative stative verb but lacks duration. In other words, Mandarin Chinese locative inversion with -zhe is only compatible with temporary stative and durative predicates: it focuses on the state after the finishing point of an action and conveys the idea that the state holds for a period of time. This receives support from Zhang (2008: 895), who argues that "-le represents a closed event, whereas -zhe is a resultative stative marker."

(vi) The difference between locative inversion constructions with -zhe and passives: As Pan notes, in passives with -le the agent can be realized with a prepositional phrase (by-phrase) but a locative inversion with -zhe cannot co-occur with that prepositional phrase.
a. Zhuozishang
bei Joh
fang
-le $y$
ben shu.
table-top
by John put
LE one CL book
'A book was put on the table by John.'
$\begin{array}{lllll}\text { b. *Zhuozishang bei John fang -zhe yi ben shu. } \\ \text { table-top } & \text { by John put }\end{array}$
'A book was put on the table by John.'
(Pan, 1996:417)

The major conclusion Pan (1996) draws for Mandarin Chinese locative inversion with transitive verbs is that the imperfective aspect marker $-z h$ e "eliminates the agent role of a verb, which therefore makes the resulting argument structure similar to that of an unaccusative verb" (p.411). Furthermore, verbs that are compatible with such a construction are resultative verbs that also entail duration of the state of the theme. This state of affairs makes locative inversion in Mandarin Chinese with -zhe the equivalent of stativized locative inversion in Kinyarwanda.

I will show in section 4 that all the six facts above are also found in stativized locative inversion in Kinyarwanda with the aspectual marker $-y e$. Before I proceed to the comparison, I give a background to locative inversion in Kinyarwanda in section 3.1, and the use of the aspectual morpheme -ye in stative constructions in section 3.2:

\section{Kinyarwanda Stative Locative Inversions}

\subsection{Types of Locative Inversion}

Kinyarwanda has two types of locative inversion: Formal and semantic locative inversion (Buell, 2007) as illustrated by the following examples:

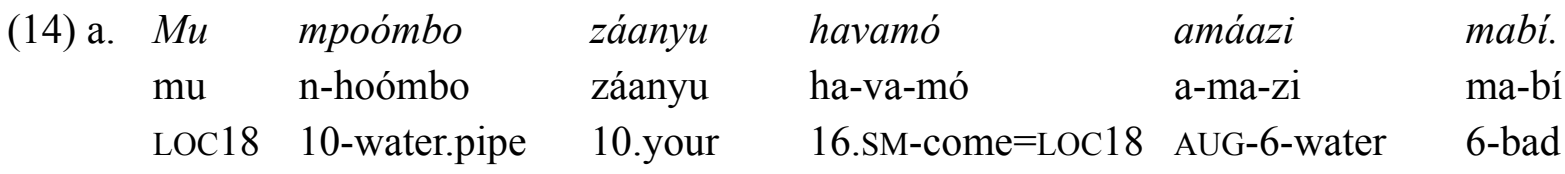
'From your pipes comes bad water.'
b. Impoómbo
záanyu
zivamó
amáazi
mabí.
i-n-hoómbo
záanyu zi-va-mó
a-ma-zi
ma-bí
AUG-10-water.pipe 10.your
16-come=LOC18 AUG-6-water
6-bad
'From your pipes comes bad water.'

The type of locative inversion in (14a) is known as formal locative inversion. The locative 
expression (the locative noun and the locative marker mu mpoómbo) precedes the verb and the theme is expressed post-verbally. The example in (14b) is the type of locative inversion called semantic locative inversion. In this construction, the locative noun without a locative marker impoómbo precedes the verb.

The verb in (14) is intransitive, specifically an unaccusative verb, but the kind of locative inversion we are concerned with in this paper is the one with a transitive verb. The structures in (15) below are similar to those in (14); the difference is that the verb in (15) is transitive.
a. $M u \quad n z u \quad$ habiitsemó
mu n-zu ha-biik-ye-mó
impapuro.
LOC18 9-wall
16.SM-keep-ASP $=\mathrm{LOC} 18$
i-n-papuro
Lit: 'In the house is kept paper.'
b. Inzu
ibiitsemó
i-n-zu
i-bíik-ye-mó
impapuro.
AUG-9-house
9.SM-keep-APS $=$ LOC18
i-n-papuro
Lit: 'The house is kept in paper.'
AUG-10-paper

Like in (14) the locative expression $m u$ nzu 'in the house' or the locative NP inzu 'house' precedes the verb and the theme follows, with the structure Loc-Verb-Theme. The verb bears the perfective aspect marker $-y e$, and no agent is expressed; its addition would render the sentence ungrammatical.

The comparison between Mandarin Chinese and Kinyarwanda locative inversion will be based on examples like (15), constructions which I call stative locative inversion. Either a formal or semantic locative inversion example or both will be used in the discussions that follow for illustration purposes.

Before proceeding to the overview of locative inversion in Kinyarwanda, I wish to point out that this type of locative inversion is possible only with the perfective aspect $-y e$, which, in fact, is used not only as an aspect marker, but also as a stativizer.

\subsection{Stativization in Kinyarwanda}

Stativization is a process by which the agent is deleted; as Kimenyi (1980) notes, stativization is a way of expressing the state of the patient/theme resulting from some action of the agent. Besides deleting the agent, stativization promotes the patient or theme to the subject position (Ngonyani, 2016). In Kinyarwanda stativization is possible only with the perfective aspect marker -ye (imperfective aspect markers $-a$ and $-a g a$ are prohibited). I illustrate stativization with two examples shown in (16b) and (17b), which correspond to active transitive constructions in (16a) and (17a).
a. Umukózi
yasukuye
inzu.
u-mu-kózi
a-a-sukur-ye
i-n-zu
AUG-1-worker
1.SM-RECP-clean-ASP AUG-9-house
'The worker has cleaned the house.'
b. Inzu
irasukuye.
i-n-zu
i-ra-sukur-ye
AUG-9-house
9.SM-DJ-clean-ASP
'The house is clean(ed).' 

a. Abagabo buubatse
inzu
néezá.
a-ba-gabo
ba-úubak-ye
i-n-zu
néezá
AUG-2-man 2.SM-build-ASP AUG-9-house
well

'The men have built the house well.'
b. Inzu yuubatse néezá.
i-n-zu i-úubak-ye néezá.
AUG-9-house 9SM-build-ASP well

'The house is well built.'

Two facts must be emphasized in the above examples: the verbs are transitive; in the a-examples, the verb selects an agent while in the b-examples, the agent is eliminated and the construction becomes a stative one in which the state of the theme is highlighted (i.e. the state of the house being cleaned in (16) or being built in (17)).

As is indicated in Michaelis (2011), stativization expresses states in two ways: lexically (i.e. semantically) and morphologically (by inflection). While stativization in (16b) and (17b) is rendered morphologically by the aspect marker $-y e^{3}$ by turning an active verb into a stative one, there are very similar constructions in which the verb typically expresses a state rather than an action, hence incompatible with the agent. Examples of verbs that express the state include the following: kurwáara 'to be sick', gukena 'to be poor' gusoonza 'to be hungry', guhaaga 'to be full'. Posture verbs such as gupfúkama 'to kneel', guhágarara 'to stand', kwéegama 'lean', also often appear in stative constructions when focus is on the durative aspect of the action after its accomplishment. Two examples illustrate this:

(18) Umwáana ararwáaye.

u-mu-áana a-ra-rwáar-ye

AUG-1-child 1.SM-DJ-be.sick-ASP

'The child is sick.'

Abanyéeshuúri barapfúkamye.
$\begin{aligned} & \text { a-ba-nyéeshuúri ba-ra-pfúkam-ye } \\ & \text { AUG-2-student } \quad 2 . S M-D J-k n e e l-A S P\end{aligned}$
'The students are kneeling down.'

The comparison will not be concerned with constructions such as (18) and (19), which are based on unaccusative and inherently stative verbs. It will instead concern transitive verbs mentioned in the introduction, notably placement verbs, which are action verbs but are turned into stative ones.

Note that it is possible to express the state in the past, present or future time with the same suffix $-y e$. This is illustrated in (20) for a past state and (21) for a future state. Notice also that Kinyarwanda stativized constructions require the auxiliaries $b a$ in the past and $r i$ in the future, both of which correspond to "be" in English".

\footnotetext{
${ }^{3}$ In contrast to languages like French in which stativization can be marked with an imperfective or progressive morphology (Michaelis, 2011), in Kinyarwanda, it is only the perfective aspect marker that marks stativization.
} 
(20)
a. Inzu
yári
yúubatse.
i-n-zu
i-á-ri
i-úubak-ye
AUG-9-house
9.SM-REMP-be
9.SM-build-ASP
'The house was build.'
b. Umwáana yarí
arwáaye.
u-mu-áana a-á-ri
a-rwáar-ye
AUG-1-child 1.SM-REMP-be
1.SM-be.sick-ASP
'The child was sick.'
a. Inzu
izaaba
yúubatse.
i-n-zu
i-za-bá
i-úubak-ye
AUG-9-house
9.SM-FUT-be
9.SM-build-ASP
'The house will be build.'
b. Umwáana azaaba arwáaye.
u-mu-áana a-za-bá a-rwáar-ye
AUG-1-child 1.SM-FUT-be 1.SM-be.sick-ASP
'The child will be sick.'

(21)

In contrast, a verb such as gukúbita 'beat', which expresses neither a state nor duration after accomplishment, does not allow the use of the auxiliary 'be'.

$$
\begin{aligned}
& \text { *Umwáana azaaba akúbise. } \\
& \text { u-mu-áana a-za-bá a-kúbit-ye } \\
& \text { AUG-1-child 1.SM-FUT-be 1.SM-beat-ASP } \\
& \text { Intended: 'The child will be beaten.' }
\end{aligned}
$$

Based on the details presented in this section, I will provide in section 4 a detailed comparison of the Mandarin Chinese locative inversion constructions and Kinyarwanda stative locative inversion. It will be suggested that in stativized locative inversion in Kinyarwanda, the perfective aspect morphemes -ye functions as a stative marker and performs the same function as the Mandarin Chinese imperfective aspect marker $-z h e$ : it deletes the agent, turns an active construction into a stative/unaccusative one, which confirms Pan's (1996:415) view that in such constructions, "verbs acquire unaccusativity only after the morphological operation induced by the morpheme -zhe." I also show that locative inversion in Mandarin Chinese and stative locative inversion in Kinyarwanda share some restrictions, such as for example, disallowing verbs like 'put' or 'beat', which do not entail duration of the state of the result after an action has been accomplished.

\section{Comparison}

The comparison of Mandarin Chinese locative inversion with -zhe and stative locative inversion in Kinyarwanda will be based on the 6 facts highlighted in section 3, and the following examples from Kinyarwanda. 


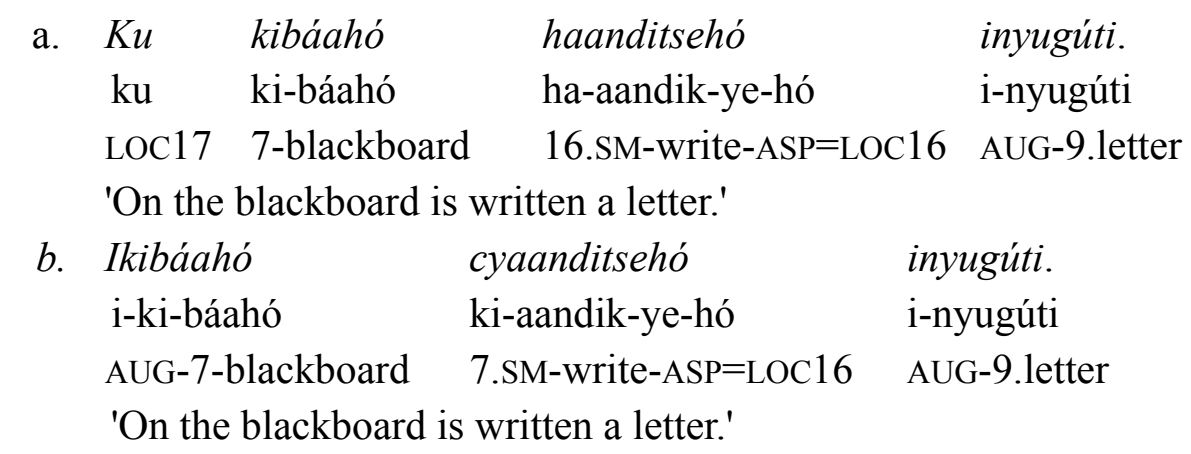

The comparison is structured as follows: argument structure, agent deletion, mapping of the theme to the subject position, impossibility of omission of the theme NP, restrictions on inversion with some placement verbs, and the difference between passive and locative inversion in Mandarin Chinese and Kinyarwanda stative locative inversion.

Argument structure: Transitive verbs that allow stativized locative inversion in Kinyarwanda are exactly the same as those exemplified in Mandarin Chinese, namely placement verbs. The following Mandarin Chinese transitive verbs are mentioned in Pan (1996) as allowing locative inversion: xie 'write, gua 'hang', tie 'stick'. Exactly the same type of verbs occur in stative locative inversion in Kinyarwanda: kwaandika 'write', kumanika 'hang', kóomeka 'stick. To this list can be added the following verbs in Kinyarwanda, which also share the semantic property of being placement verbs: gushushaanya 'to draw', kubiika 'to keep', kuruunda 'to pile', kubádika 'to stick', kuraambika 'place/lay', gusasa 'lay' (e.g. cover the floor with e.g. bricks, tiles), kurambuura 'unfold/spread', gupfúka 'to cover', gutwiikira 'cover'. Any of these verbs can appear in stativized locative inversion without any restriction.

As is the case in Mandarin Chinese (see Zhang, 2008:895), stative sentences such as those in (23) require a transitive (placement) verb whose accomplishment results in a state; some accomplishment verbs such as 'beat' cannot be used in this way.
a. Uweéra
akubise Ngeenzi
Uweéra
a-kúbit-ye Ngeenzi
$m u$
$\mathrm{mu} \quad$ mu-twé
1. Uweéra
1.SM-hit-ASP
1.Ngeenzi
LOC18 3-head
'Uwera has hit Ngenzi in the head.'
b. *Mu mutwé hakubise Ngeenzi.
mu mu-twé ha-kúbit-ye Ngeenzi
LOC18 3-head 16.SM-hit-ASP 1.Ngenzi
Intend: 'Ngenzi is hit in the head.'

Agent deletion: Another feature of both Mandarin Chinese locative inversion with the aspectual morpheme -zhe and stative locative inversion in Kinyarwanda is the impossibility of agent expression. The examples in (4b) and (5) repeated here as (25) and (26) illustrate that.

\begin{tabular}{|c|c|c|c|c|}
\hline * Heibanshang & John & xie -zhe & yi & ge zi. \\
\hline blackboard-on & John & write ZHE & one & character \\
\hline
\end{tabular}


$(26) * K$

\begin{tabular}{llcl}
\multicolumn{2}{c}{$\begin{array}{c}\text { kibáahó } \\
\text { ki-báahó }\end{array}$} & \multicolumn{2}{c}{ haanditsehó } \\
ha-aandik-ye-hó & \multicolumn{2}{c}{ i-nyugúti } & Yohaáni. \\
ku & 7-blackboard & 16.SM-write-ASP=LOC16 & AUG-9.letter John \\
LOC18 & 7-blackbord &
\end{tabular}

The data show that the Mandarin Chinese and Kinyarwanda examples above are stative constructions; hence, they are incompatible with the agent. Following Pan (1996), I suggest that in both languages, once the agent is deleted, the construction becomes unaccusative. In that case, either the locative noun or the theme can become the grammatical subject of the sentence.

Note, however, that the Kinyarwanda example in (26) can be marginally acceptable if it is a case of locative inversion without a stative reading. It must also be pointed out that in case (26) is not a stative construction, but simply an inversion construction, the verb can appear in different tenses (past, present, and future).

Mapping of the theme to the subject position: With agent deletion, it is possible for the theme to be mapped to the subject function in Mandarin Chinese with the aspectual morpheme -zhe (when the theme is definite), with the locative following the theme.
Nage zi
that character at blackboard-on write ZHE
'That character is written on the blackboard.' (Pan, 1996:413)

The expression of the theme/patient in subject position instead of the agent is typical of stativization (see Ngonyani, 2016).

The theme in subject position instead of the agent in (27) is also available in Kinyarwanda stative constructions. The example in (28) corresponds to (27).

$$
\begin{array}{llll}
\text { Inyugúti } & \text { yaanditse } & k u & \text { kibáahó. } \\
\text { i-nyugúti } & \text { i-aandik-ye } & \mathrm{ku} & \text { ki-báahó } \\
\text { AUG-9.letter } & \text { 9.SM-write-ASP } & \text { LOC17 } & \text { 7-blackboard }
\end{array}
$$

'The letter is written on the blackboard.'

It should be stressed here that agent deletion in Kinyarwanda is not triggered by the presence of a locative expression expressed post-verbally as in (27) and (28); it is possible in constructions with or without a locative expression. The locative expression in (27) is omitted in (29) below, and the sentence remains grammatical (see similar examples in (17) and (18)):

$$
\begin{aligned}
& \text { Inyugúti iraanditse. } \\
& \text { i-nyugúti i-ra-aandik-ye } \\
& \text { AUG-9.letter 9.SM-DJ-write-ASP } \\
& \text { 'The letter is written.' }
\end{aligned}
$$

Recall that sentences like (29) are grammatical if the verb allows its accomplishment to result in a state. Thus in (29), the letter is on the board and stays there. In contrast to (29), the example in (30) is ungrammatical because the accomplishment of the verb does not entail a state.

$$
\begin{aligned}
& \text { *Ngeenzi arakúbise. } \\
& \text { Ngeenzi a-ra-kúbit-ye } \\
& \text { 1.ngenzi 1SM-DJ-hit-ASP } \\
& \text { 'Ngenzi is hit.' }
\end{aligned}
$$


Unfortunately, from the data available, we don't know whether Mandarin Chinese would allow the dropping of the locative expression in case the theme is mapped onto the subject position as in (29).

Impossibility of omission of the post-verbal Theme NP: Zhang (2008:897) points out that the postverbal theme NP in Mandarin Chinese locative inversion can be omitted with the aspectual -le if it can be recovered from the context. In contrast, when it is omitted with the aspectual $-z h e$, the sentence becomes ungrammatical. This is illustrated by the example in (10) repeated here as $(31)$ :

a. zhe zhang zhi shang (yijing) xie le (zi), ni xie na zhang ba.

this CLS paper on already write LE character, you write that CLS particle

'This piece of paper is already written on. You write on the other one.'

b. zhe zhang zhi shang xie zhe *(zi), ni xie na zhang ba.

Similarly to Mandarin Chinese locative inversion with -zhe, Kinyarwanda stativized locative inversion does not allow the omission of the postverbal theme NP as is the case in (32).
a. $K$
méezá haraambitsehó
*(ibitabo)
ku méezá ha-raambik-ye-hó
i-bi-tabo
LOC17 6.table 16.SM-place-ASP=LOC17 AUG-8-books
'Books are placed on the table.'
b. Améezá araambitsehó *(ibitabo).
a-méezá a-raambik-ye-hó i-bi-tabo
AUG-6.table 6.SM-place-ASP=LOC18 AUG-8-books
'Books are placed on the table.'

Note, however, that with transitive verbs such as kwaandika 'write', which are sometimes used intransitively, it is also possible to omit the theme.
a. Ku kibáahó
ku ki-báahó
haanditsehó
(inyugúti).
LOC18 7-blackboard
ha-aandik-ye-hó
i-nyúguti
16.SM-write-ASP $=$ LOC16 AUG-9.letter
Lit: 'On the blackboard is written.'
b. Ikibáahó
cyaanditsehó
i-ki-báahó
ki-aandik-ye-hó
(inyugúti).
AUG-7-blackboard
7.SM-write-ASP $=\mathrm{LOC} 16$
i-nyugúti
Lit: 'On the blackboard is written'

In this regard, Kinyarwanda locative inversion with verbs such as 'write' is similar to inversion with -le in Mandarin Chinese while inversion with other transitive verbs such as 'place' is similar to locative inversion with -zhe. Where does the contrast between (32) and (33) come from? In other words, why is it possible to omit the postverbal NP in (33) but impossible in (32)? The most likely explanation is that in (33), the theme NP is optional even in a non-inverted construction; therefore, its omission does not affect the grammaticality of the sentence. In contrast, in (32) the theme is required; so its omission renders the construction ungrammatical. Based on the data available, I conclude that in terms of omission of the theme NP, Mandarin Chinese locative inversion with -zhe patterns like Kinyarwanda stative locative inversion.

The apparent exception with the verb 'put': Pan (1996) shows that in Mandarin Chinese, the 
verb fang 'put' does not appear in locative inversion with the aspectual marker -zhe despite its being a placement verb.

$\begin{array}{lllll}\text { *Zhuozishang } & \text { fang } & \text { man } & \text {-zhe } & \text { shu. } \\ \text { table-top } & \text { put } & \text { full } & \text { ZHE } & \text { book }\end{array}$

'Books are put all over the table.'

Pan suggests that although the verb fang 'put' is a resultative/accomplishment verb, its failure to appear in locative inversion with -zhe is due to its lack of duration.

A similar phenomenon is observed in Kinyarwanda. Like in Mandarin Chinese, the verb gushyira 'put' does not permit this type of locative inversion despite its being a placement (and resultative/accomplishment) verb. This is illustrated by the ungrammatical examples in (35):

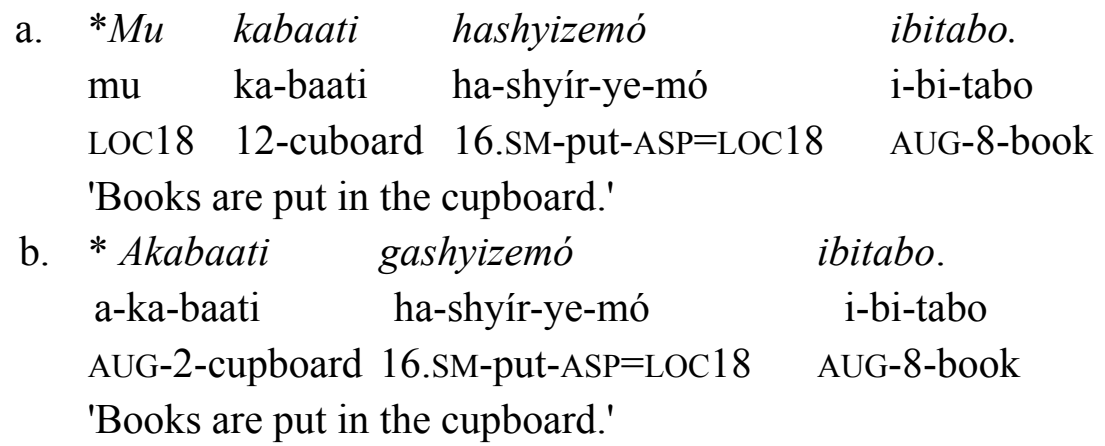

The argument presented for Mandarin Chinese is also valid for Kinyarwanda. Verbs such as gushyira 'put' are resultative/accomplishment placement verbs, but they fail to appear in the type of locative inversion under discussion because they lack duration. They rather behave like other transitive verbs that generally lack duration, including gukúbita 'beat', gutá 'throw', gusiimbuka 'jump'. However, to express the resulting state of the action of gushyira 'put' in Kinyarwanda, other placement verbs closer in meaning to gushyira 'put', but which differ from it in terms of duration of the action, are used. One such example is the verb kuraambika 'place' which appears in the example in (32) above.

Stativized vs. passivized locative inversion: Pan (1996) notes that passive constructions are different from locative inversion with $-z$ he in Mandarin Chinese. He shows that locative inversion with -zhe is incompatible with the "bei passive" while passivization is not normally prohibited in locative inversion. This is illustrated by the ungrammatical example in (35a) and the grammatical example in (36b).

a. *Zhuoshang bei John fang -zhe yi ll ben
table-top by John put
'On the table was put one book.'
a. Zhuoshang bei John fang
table-top by John put
'On the table was put one book.'

Kinyarwanda also exhibits similar differences between stative locative inversion and passives constructions. Differences between the two constructions are presented in detail in Ngoboka (2016). Compare the stative sentence in (37b) and the corresponding passive in (37c), both of which correspond to the S-V-O-Loc construction in (37a), in which the agent is the subject of the sentence. 
a. Mariyá yaanditse

inyugúti ku kibáahó.

Mariyá a-a-aandik-ye i-nyugúti ku ki-báahó

1.Mary 1.SM-RECP-write-ASP AUG-9.letter LOC17 7-blackboard

'Mary wrote a letter on the blackboard.'
b. *Ikibáahó
cyaanditsehó
inyugúti
na Mariyá.
i-kibáahó
ki-aandik-ye-hó
i-nyugúti na Mariyá
AUG-7-blackboard
7.SM-write-ASP $=\mathrm{LOC} 16$
AUG-9.letter by Mary

Lit: 'The blackboard is written a letter by Mary.'

'A letter is written on the blackboard by Mary.'
c. Ikibáahó
cyaanditswehó
inyugúti
na Mariyá.
i-kibáahó
ki-a-aandik-w-ye-hó
i-nyugúti
naMariyá
AUG-7-blackboard 7.SM-RECP-write-PASS-ASP=LOC16 AUG-9.1etter by Mary
Lit: 'The blackboard has been written a letter on by Mary.'

As we can see from these examples, the passive differs from the stative morphologically, syntactically and semantically. Morphologically, the passive is expressed with the morpheme $-w$ while the stative has no specific marker besides the aspectual morpheme $-y e$. Syntactically, it is possible to add the agent to the sentence in an agent by-phrase in a passive construction but like in Mandarin Chinese constructions, the agent is prohibited in any position in a stativized locative inversion construction. Semantically, stative locative inversion expresses a state as is suggested by the word 'stative'. For example, the meaning of (37b) is that there is a letter written on the board. As for the passive sentence, it expresses an event; someone has written the letters on the blackboard. Unfortunately, the difference between the stative and passive constructions cannot be captured in the English translation.

Another difference between Mandarin Chinese locative inversion with -zhe and passives in the same language worth highlighting here is that manner and intentional adverbs are disallowed in locative inversion but possible in passives.

$$
\begin{aligned}
& \text { *Zhuozishang guyi/manmande fang-zhe yi ben shu. } \\
& \text { table-top on-purpose/slowly put ZHE one CL book } \\
& \text { 'A book was put on the table on purpose/slowly.' (Pan, 1996:430) } \\
& \text { Zhuan bei John guyi/manmande cheng -le. } \\
& \text { boat by John on.purpose/slowly sink PERF } \\
& \text { 'The boat was sunk on purpose/slowly.' (Pan, 1996:430) }
\end{aligned}
$$

We observe a similar pattern in Kinyarwanda. The stative locative inversion construction in (40a) is ungrammatical because a manner adverb is added, but this does not apply to the passive construction in (40b), which remains grammatical when the same manner adverb is used. 


$\begin{array}{lllll}\mathrm{mu} & \text { ki-uúmba } & \text { ha-sas-ye-mó } & \text { a-ma-karo } & \text { vubá } \\ \text { LOC18 } & \text { 7-room } & \text { 16.SM-lay=LOC18 } & \text { AUG-6-tile } & \text { quickly }\end{array}$

Lit: 'In the room are laid tiles quickly.'

b. Mu cyuúmba haashashwemó

amakaro vubá.

mu ki-uúmba ha-a-sas-w-ye-mó

a-ma-karo vubá

LOC18 7-room 16.SM-RECP-lay-PASS-ASP=LOC18 AUG-6-tile quickly

Lit: 'In the room have been laid tiles quickly.'

It is worth emphasizing that passivized locative inversion in Kinyarwanda allows the use of different aspect markers (i.e. imperfective aspect markers - $a$ and -aga besides the perfective marker-ye). This is in sharp contrast with stative constructions or the type of locative inversion we have discussed, which is possible only with the perfective aspect marker $-y e$.

\section{5. - Ye and -zhe Are Stativizers}

Based on the discussion in the previous sections, I show in this section that the morphemes $-y e$ and $-z h e$ are just stativizers and that the constructions we have dealt with are stative, which only happen to appear as locative inversion. This can be elaborated as follows.

The Kinyarwanda morpheme -ye is polysemous: it is a perfective aspect marker, but it also serves as a stativizer. This is shown in (41) below:
a. Umuhíinzi yaruunze
ubwaátsi
$m u$
u-mu-híinzi a-a-ruund-ye
u-bu-aátsi
$\mathrm{mu}$
AUG-1-farmer SM.1-PST-pile-ASP
AUG-14-grass
'The farmer piled up grass in the field.'

$\begin{array}{llll}\text { b. Ubwaátsi buruunze } & m u & \text { murimá. } \\ \text { u-bu-aátsi bu-ruund-ye } & \mathrm{mu} & \text { mu-rimá } \\ \text { AUG-14-grass } \quad \text { SM.18-pile-ASP } & \text { LOC18 } & \text { 3-field }\end{array}$
'The grass is piled up in the field.'

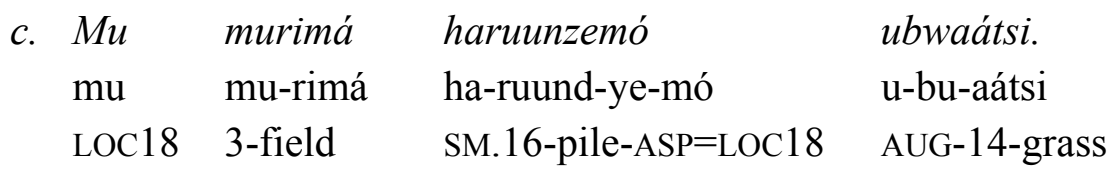

murimá.

mu-rimá

LOC18 3-field

'In the field is piled grass.'

As an aspect marker, the morpheme -ye can appear with any verb and in a construction like (41a) where the agent is expressed. As a stativizer, it is used in sentences like $(41 \mathrm{~b}, \mathrm{c})$ in which the agent is deleted (see similar examples in Kimenyi 1980). In this sense, it is also used with typically stative verbs such as kurwáara 'to be sick', where the construction is unaccusative. Semantically, the examples in $(41 b, c)$ are cases in which the verb expresses a state of the theme after the finishing of the action, and this state must hold for a certain amount of time. A similar observation is made in Pan (1996:416) about Mandarin Chinese. Pan notes that in locative inversion, the morpheme -zhe focuses "on the state after the finishing point and conveys the idea that the state holds for a period of time". Put differently, stative constructions entail the absence of the agent and a (durative) state.

We have also seen that in Kinyarwanda, in the absence of the agent, either the locative expression or the theme can be mapped to the subject position, (23) and (28). This is also true for Chinese; if the agent is not expressed, either the theme or the locative can occupy the 
subject position. This results in a typical stative construction similar to stative constructions with inherently stative verbs such as kurwáara 'to be sick' or gukena 'to be poor' (see examples in (18)- (20) above).

In short, what is true for the stative locative inversion in Kinyarwanda as discussed above is also true for Mandarin Chinese locative inversion with the morpheme -zhe: the agent is prohibited and cannot appear even as a by-agent phrase and, in the absence of the agent, the locative and the theme can alternate in subject position. Furthermore intentional and manner adverbs are prohibited. From this, I propose that Kinyarwanda stative locative inversion and Mandarin Chinese locative inversion with $-z h e$ are primarily stative constructions. Only the locative expression happens to be placed in the subject position. If the locative is in the subject position, it is a case of stative locative inversion. If it follows the theme in Mandarin Chinese or is expressed post-verbally in Kinyarwanda, it is just a stative construction. It could be added for Kinyarwanda that the constructions we have dealt with are cases of stativization in that they are not possible with non-perfective aspect markers -aga and $-a$, which are incompatible with stativization. This is why $(42 \mathrm{~b}, \mathrm{c})$ are ungrammatical: their ungrammaticality is simply due to the use of the imperfective aspect marker $-a$ instead of the perfective aspect marker -ye like in (41) above.

$$
\begin{aligned}
& \text { a. Umuhíinzi aruunda } \\
& \text { u-mu-híinzi } \\
& \text { a-a-ruund-a } \\
& \text { ubwaátsi } \\
& \text { ти murimá. } \\
& \text { AUG-1-farmer } \\
& \text { SM.1-PST-pile-IMPF } \\
& \text { u-bu-aátsi } \\
& \mathrm{mu}
\end{aligned}
$$

\begin{tabular}{|c|c|c|c|}
\hline $\begin{array}{l}* M u \\
\mathrm{mu}\end{array}$ & $\begin{array}{l}\text { murimá } \\
\text { mu-rimá }\end{array}$ & $\begin{array}{l}\text { haruundamó } \\
\text { ha-ruund-a-mó }\end{array}$ & $\begin{array}{l}\text { ubwaátsi. } \\
\text { u-bu-aátsi }\end{array}$ \\
\hline LOC18 & 3-field & SM.16-pile-IMPF=LOC18 & AUG-8-grass \\
\hline
\end{tabular}$$
\text { mu-rimá }
$$

$\begin{array}{llll}\text { b. *Ubwaátsi } & \text { buruunda } & m u & \text { murimá. } \\ \text { i-bi-aátsi } & \text { bu-ruund-a } & \text { mu } & \text { mu-rimá } \\ \text { AUG-8-grass } & \text { SM.14-pile-IMPF } & \text { LOC18 } & \text { 3-field }\end{array}$

'In the field piles up grass.'

In $(42 b, c)$, it suffices to replace the imperfective aspect marker - $a$ with the perfective aspect marker -ye to have a grammatical sentence.

\section{Conclusion}

The paper has highlighted similarities between Mandarin Chinese locative inversion and Kinyarwanda stative locative inversion. Despite the fact that the two languages are genetically unrelated, the constructions discussed in this paper share a number of properties such disallowing the agent, being based on the same types of verbs (transitive verbs called placement verb), disallowing placement verbs like put despite the fact that they are also placement verbs, disallowing deletion of the theme, etc. The process turns a transitive construction into an accusative construction, and this makes it possible for the theme or the locative expression to precede the verb. It would be interesting to extend this study to other very genetically different languages to see whether the same structures and restrictions can be found there. 


\section{Macrothink}

\section{References}

Bresnan, J., \& Kanerva, J. M. (1989). Locative inversion in Chicheŵa: a case study of factorization in grammar. Linguistic Inquiry, 20(1), 1-50.

Buell, L. (2007). Semantic and Formal Locatives: Implications for the Bantu Locative. SOAS Working Papers in Linguistics, 15, 105-120.

Khumalo, L. (2010). Passive, locative inversion in Ndebele and the unaccusative hypothesis. South African Journal of African Languages, 30(1), 22-34.

Kimenyi, A. (1980). A Relational Grammar of Kinyarwanda. Berkeley: University of California Press.

Marten, L. (2006). Locative Inversion in Otjiherero: More on morphosyntactic variation in Bantu. ZAS Papers in Linguistic, 43, 97-122.

Marten, L., Kula, N. C., \& Thwala, N. (2007). Parameters of morphosyntactic variation in Bantu. Transactions of the Philological Society, 105 (3), 253-338. https://doi.org/10.1111/j.1467-968X.2007.00190.x

Marten, L., \& van der Wal, J. (2015). A typology of Bantu inversion constructions. Linguistic variation yearbook, 14(2), 318-368. https://doi.org/10.1075/lv.14.2.04mar

Michaelis, L. A. (2011). Stative by construction. Linguistics, 49(6), 1359-1399. https://doi.org/10.1515/ling.2011.038

Ngoboka, J. P. (2016). Locatives in Kinyarwanda. (PhD), University of KwaZulu Natal, Durban.

Ngonyani, D. S. (2016). Pairwise Combinations of Swahili Applicative with other Verb Extensions. Nordic Journal of African Studies, 25(1), 52-71.

Pan, H. H. (1996). Imperfective aspect zhe, agent deletion, and locative inversion in Mandarin Chinese. Natural Language \& Linguistic Theory, 14(2), 409-432. https://doi.org/10.1007/BF00133688

Zalzmann, M. (2011). Towards a typology of Locative Inversion-Bantu, perhaps Chinese and English-but beyond? Language and Linguistics Compass, 5(4), 169-189. https://doi.org/10.1111/j.1749-818X.2011.00270.x

Zhang, L. (2008). Locative inversion and aspect markers of le and zhe in Mandarin Chinese. Proceedings of the 20th North American Conference on Chinese Linguistics (NACCL-20). Vol. 2, edited by Marjorie K. M. Chan and Hana Kang, 893-902. Columbus, Ohio: Ohio State University.

\section{Copyright Disclaimer}

Copyright reserved by the author(s).

This article is an open-access article distributed under the terms and conditions of the Creative Commons Attribution license (http://creativecommons.org/licenses/by/3.0/). 